\title{
Grzegorz Lubeńczuk
}

Maria Curie-Skłodowska University in Lublin, Poland

ORCID: 0000-0001-5028-8020

lubenczuk@umcs.pl

\section{The Concept of the Normative Dereification of an Animal in Polish Law*}

\author{
Koncepcja normatywnej dereifikacji zwierzęcia w polskim prawie
}

\begin{abstract}
The subject of the article is normative dereification, which was enacted in the Polish legal system on the basis of the provisions of the Act of 21 August 1997 on animal protection. These provisions indicate that an animal, as a living being capable of experiencing suffering, is not a thing, and at the same time they stipulate the need for the appropriate application of the provisions on things to animals in matters not regulated by this Act. The aim of the article is to determine the significance of such dereification for the definition of the legal status of an animal in Polish law, and its impact on the form of the model of animal protection in Poland. The basis of the findings in this respect is a formal legal analysis of the Polish legal acts regulating the principles of animal protection, and animals' status as the object of a legal relationship. The study organises and summarises the views on the legal standing of animals, and the concept of their normative dereification, as expressed in the rulings of Polish courts, and in the Polish legal literature.
\end{abstract}

Keywords: animal; dereification; reification; animal protection; legal status of an animal; Polish law

CORRESPONDENCE ADDRESS: Grzegorz Lubeńczuk, PhD, Assistant Professor, Maria Curie-Skłodowska University (Lublin), Faculty of Law and Administration, Institute of Law, Plac Marii Curie-Skłodowskiej 5, 20-031 Lublin, Poland.

* Publication has been prepared as part of the research project entitled "The Administrative Law Model of Animal Protection", covered by the application registered with the Funding Stream Support system administered by the National Information Processing Institute, as no. 2016/23/D/HS5/01820 and accepted for financing as part of the competition SONATA 12 held by the National Science Centre, Poland, under the decision of the Director of the National Science Centre in Kraków of 16 May 2017 (decision no. DEC-2016/23/D/HS5/01820, agreement no. UMO-2016/23/D/HS5/01820). 


\section{INTRODUCTION}

The need for the legal protection of animals and their welfare does not normally raise any doubts. The protection of animals is treated as an independent legal value. ${ }^{1}$ The status of the animal shapes its legal protection and is the main determinant of the scope of its welfare as prescribed by law. ${ }^{2}$ The human decision on the status of the animal determines the scope of its protection. ${ }^{3}$ At the same time, however, there is no single universal model for the legal protection of animals. Different countries adopt different solutions in this regard. One of the basic elements determining the model of the legal protection of animals in a given country is the way in which their status as the object of legal protection is defined. For the last few thousand years, the relationship between humans and animals has been based on the assumption that animals are things which can be owned and exploited by people in an essentially unlimited way. Also, at present animals are a source of food, a means of transport, and a source of entertainment for humans, but there is a growing conviction that although animals can be used to satisfy human needs, human control over animals cannot be unlimited, and an animal itself cannot be treated as a mere object. As a result, more and more countries are adopting regulations which break with the traditional approach of considering an animal to be the same object of legal regulation as inanimate things, and state that an animal is not an object. Such regulations have been adopted in, i.a., Austria, Germany, and Switzerland. Article 1 (1) of the Polish Act of 21 August 1997 on animal protection is also an example of such a regulation. ${ }^{4}$ This provision stipulates that an animal, as a living being capable of suffering, is not a thing, and mankind owes it respect, protection, and care. The rule emanating from the provision, according to which an animal is not a thing, determines the way in which an animal is treated as an object of Polish law, and constitutes the foundation of the animal-protection system in Poland.

The aim of this article is to determine the impact which the implementation of the principle that an animal is not a thing has on the determination of the legal status of an animal in Polish law, and on the form of the model of animal protection in Poland. An analysis necessary to produce such findings has been carried out by means of the formal-legal method based on the content of acts of Polish law regulating the legal status of animals, and the principles of their protection, as well as the views expressed in rulings of Polish courts and in the Polish legal literature.

1 B. Rakoczy, Protection of Animals and Protection from Animals, "Studia Iuridica Lublinensia" 2021, vol. 30(3), p. 163.

2 J. Goździewicz-Biechońska, E. Jachnik, Legal Status of the Animal as a Determinant of Its Humanitarian Protection, "Studia Iuridica Lublinensia" 2021, vol. 30(3), p. 68.

3 Ibidem.

4 Consolidated text, Journal of Laws 2020, item 638, hereinafter: APA. 


\section{THE NORMATIVE DEREIFICATION OF ANIMALS IN POLISH LAW}

The Act of 21 August 1997 on animal protection is the first, and, at the same time, the only Polish Act stating that an animal is not a thing. In the period before the Act came into force, the key role in determining the legal status of animals was played by the Regulation of the President of the Republic of Poland of 22 March 1928 on the protection of animals, ${ }^{5}$ which regulated the principles of the humane protection of animals, and the Act of 23 April 1964 - Civil Code, ${ }^{6}$ which is still in force today, and which dictates the status of an animal as an object of civil-law relationships. Neither of these legal acts directly stipulated that an animal was, or was not, a thing. The provisions of the Regulation of 22 March 1928 guaranteed animals protection against abuse; at the same time, however, the provisions of the Civil Code disregarded the specific nature of an animal and merely regulated the principles of possession and trade in things, which made it necessary to apply those principles also to animals. The situation of animals was regulated differently only with regard to the principles of liability for damage caused by an animal, and the rights of the aggrieved party in such a case. A change in the way in which the legislator perceived animals occurred only on the entry into force of the Animal Protection Act.

Article 1 (1) APA provides that an animal, as a living being capable of suffering, is not a thing. The change whereby the legislator recognises that animals are not things is referred to in the Polish legal literature as "dereification" (de-objectification). ${ }^{7}$ Dereification is defined as considering previously treated as a thing to be an object which is not a thing, and is treated as the antonym of the term "reification" (from the Latin res, "thing"), which means treating something which is not a thing as a thing. ${ }^{8}$ The Polish Supreme Court points out that the essence of dereification is the assumption that an animal is not a material object but a living being capable of feeling suffering, and as such is excluded from the category of material objects. ${ }^{9}$ However, the dereification enacted by Article 1 (1) APA has only a normative dimension and produces effects only in terms of the legislator's perception of animals. Dereification does not make animals living beings, just as their earlier reification did not deprive them of this attribute; but animals are not still things by their very

5 Journal of Laws 1932, item 417, as amended.

6 Consolidated text, Journal of Laws 2020, item 1740, as amended.

7 Cf. E. Łętowska, Dwa cywilnoprawne aspekty praw zwierząt: dereifikacja i personifikacja, [in:] Studia z prawa prywatnego. Księga pamiątkowa ku czci Profesor Biruty Lewaszkiewicz-Petrykowskiej, Łódź 1997, p. 71; M. Nazar, Normatywna dereifikacja zwierząt-aspekty cywilnoprawne, [in:] Prawna ochrona zwierząt, ed. M. Mozgawa, Lublin 2002, p. 129; Z. Radwański, Prawo cywilne. Czesść ogólna, Warszawa 1999, p. 113.

8 M. Nazar, op. cit., p. 129.

9 Resolution of the Supreme Court of 20 June 2012, I KZP 4/12, Legalis. 
nature and no legal regulation can change that. Neither does the content of Article 1 (1) APA determine how an animal is perceived in biological, veterinary, or philosophical terms. In its essence, dereification is only a particular concept of the normative perception of an animal in the context of defining legal limits of human control over an animal, and the necessity to provide legal protection to an animal.

\section{THE DEREIFICATION VS THE PERSONIFICATION OF THE ANIMAL}

According to the position adopted by the Supreme Court, the dereification of animals does not mean their legal personification, ${ }^{10}$ which should be understood as the recognition of an animal as a subject of law capable of having its own rights and duties. Dereification does not result in the empowering of an animal, or in its obtaining the capacity to acquire and possess rights. ${ }^{11}$ In Polish law, there are only three categories of legal entities which may have rights and duties. These are natural persons (human beings), legal persons, and organisational units which are not legal persons, to which specific provisions grant legal capacity. In each case, the decisive criterion for possessing legal personality is legal capacity, understood as the ability to have rights and duties under civil law, i.e. the ability to be a party in a civil-law relationship. ${ }^{12}$ The normative concept of legal personality has been adopted in Polish law. According to this concept, legal capacity is a normative property, which is assigned by the legislator. ${ }^{13}$ In order to speak about the legal subjectivity of animals, it would be necessary for the legislator to grant them legal capacity. The Polish literature notes that if the legislator had wanted to, it could have granted legal capacity to animals, which would thus gain the possibility to acquire rights, including property rights (e.g., by inheritance or donation).${ }^{14}$ However, the Polish legislator does not grant this capacity to animals. Moreover, at the stage of the work on the draft of the currently binding Constitution of the Republic of Poland of 2 April 1997, ${ }^{15}$ the National Assembly almost unanimously rejected an amendment to Article 5 of this draft, which provided for the principle of respect for "animal rights", and not a single provision on the legal status of animals was included in the Constitution. Consequently, although some authors maintain that normative dereification means that an animal has become a subject in public and

${ }^{10}$ Ibidem.

${ }^{11}$ Cf. M. Nazar, op. cit., p. 138.

12 P. Księżak, [in:] Kodeks cywilny. Komentarz, ed. K. Osajda, Legalis 2021; R. Strugała, [in:] Kodeks cywilny. Komentarz, eds. E. Gniewek, P. Machnikowski, Legalis 2019.

13 M. Nazar, op. cit., p. 134.

${ }^{14}$ Ibidem, p. 138.

15 Journal of Laws 1997, item 483, as amended. English translation of the Constitution at: www. sejm.gov.pl/prawo/konst/angielski/kon1.htm [access: 10.10.2021]. 
private law, ${ }^{16}$ it should be concluded that in the light of Polish law, an animal has no rights and cannot be the subject of any legal duties. It is emphasised that respect, protection, and care as indicated in Article 1 (1) sentence 2 have not been treated by the legislator as animal rights, but as the duty of humans. ${ }^{17}$ Animals are not capable of acting independently in the legal domain, ${ }^{18}$ and are not responsible for the damage they cause. However, this does not change the fact that, as living beings, they are subject to special protection, which does not permit them to be treated entirely as things. Against this background, there are proposals to speak in the case of animals of a "functional subjectivity", which is fundamentally different from that granted to human beings, and results from human respect for the general value of life, and the acceptance of the imperative that suffering is a moral evil. ${ }^{19}$

\section{THE SCOPE OF THE NORMATIVE DEREIFICATION OF ANIMALS}

The dereification, as enacted under Article 1 (1) APA, covers all animals. Some doubts might be raised as to the scope of the dereification under Article 1 (1) APA, as Article 2 (1) APA stipulates that the Act only regulates the treatment of vertebrate animals, and consequently that all invertebrate animals remain outside the scope of its jurisdiction. The principles of this purpose-oriented and systemic interpretation dictate that the implementation of Article 1 (1) APA also covers invertebrate animals. The literature indicates that it is difficult to assume that the legislator's intention was to narrow down the application, in their entirety, of the provisions of the Act to vertebrates, i.e. to include only this group of animals in the dereification process. ${ }^{20}$ The extent of dereification is also not dependent in a simple manner on the animals' ability to feel pain. The very phrase referring to the ability to feel suffering does not have a normative character, and its usefulness in determining the objective scope of dereification is limited, because it would be difficult to assume that the legislature has simply assumed that all animals have such an ability and it is also difficult, even in the current state of scientific knowledge, to unambiguously decide which of them do not possess such a feature. ${ }^{21}$

${ }^{16}$ Cf. J. Helios, W. Jedlecka, A. Ławniczak, Aspekty prawne, filozoficzne oraz religijne ochrony roślin i zwierzat - wybrane zagadnienia, Wrocław 2016, p. 78.

17 W. Radecki, Ustawa o ochronie zwierzą, Wrocław 2003, p. 27.

18 Judgement of the Voivodeship Administrative Court in Kraków of 13 September 2016, II SA/ Kr 398/16, CBOSA.

19 J. Białocerkiewicz, Status prawny zwierzat. Prawa zwierząt czy prawna ochrona zwierząt, Toruń 2005, p. 218.

${ }^{20}$ Cf. M. Goettel, Sytuacja zwierzęcia w prawie cywilnym, Warszawa 2013, p. 43.

${ }^{21}$ E. Kruk, Legal Status of Animals in Poland, "Studia Iuridica Lublinensia" 2021, vol. 30(3), p. 123. 
Dereification covers both domesticated and free-living animals. ${ }^{22}$ Neither the manner in which an animal is used by a human (intended use), nor the existence or absence of a relationship between an animal and a human, has any influence on the scope of the dereification as under Article 1 (1) APA. Ultimately, the view should be supported that no animal, without any exception, is a thing. ${ }^{23}$

This does not mean, however, that the legal status of all animals is the same under Polish law. The scope and forms of the protection of animals can vary, including depending on their species, or whether the animal is free or kept by humans. The Supreme Court also states that while Article 1 (1) APA enacts the dereification of all animals, another legal act regulating a different sphere of social or economic life, which also concerns the human treatment of animals, could provide for cases in which an animal shall be treated as a thing. ${ }^{24}$ In the court's opinion, such a solution will be in line with the provisions of the Animal Protection Act. ${ }^{25}$ An example of such a regulation is Article $449^{1} \S 2$ of the Civil Code, which, in defining the principles of liability for damage caused by a hazardous product, provides that animals are also considered to be products. This provision was added to the Civil Code on 1 July 2000, i.e. after the entry into force of the Animal Protection Act, and, as the literature indicates, it, in essence, re-enacts the reification of animals. ${ }^{26}$ However, it should be emphasised that the recognition of an animal as a product, enacted pursuant to Article $449^{1} \S 2$ of the Civil Code, refers only to this particular regulation, and does not deprive an animal of the protection resulting from the fact of being a living being.

\section{THE REQUIREMENT THAT PROVISIONS ON THINGS ARE APPLIED TO ANIMALS ACCORDINGLY}

While stipulating in Article 1 (1) APA that an animal is not a thing, the legislator in Article 1 (2) APA provides that in matters not regulated by the provisions of the Animal Protection Act, the provisions concerning things shall apply to animals accordingly. This does not mean, however, that the dereification of animals enacted in Article 1 (1) APA covers the provisions of this one Act. It should be assumed that Article 1 (1) APA applies to the entire system of Polish law, just as the ban on treating animals as things applies to all regulations which, at least indirectly, relate to the status of animals.

\footnotetext{
${ }^{22}$ Ł. Żelechowski, [in:] Kodeks cywilny..., ed. K. Osajda, p. 237.

${ }^{23}$ Cf. M. Goettel, op. cit., p. 46.

${ }^{24}$ Resolution of the Supreme Court of 20 June 2012, I KZP 4/12, Legalis.

25 Ibidem.

${ }^{26}$ M. Nazar, op. cit., p. 132.
} 
The dereification effected by the entry into force of Article 1 (1) APA was not accompanied by the adoption of provisions which would directly regulate the status of animals as the object of legal (in particular civil-law) relationships differently from the status of objects. Consequently, despite the unambiguous statement in the text of this provision that an animal is not a thing, ultimately the provisions concerning legal relationships in rem and trade apply to animals. ${ }^{27}$ The essence of the solution contained in Article 1 (2) APA, which allows the provisions relating to things to be applied to animals in turn, was to create an opportunity for the authority applying these provisions to depart from the uniform meaning given to them by the legislator for the purposes of qualifying legal relationships concerning things, and to adopt such an understanding of these provisions as would allow the taking into account of the differences between animals and things, in particular their capacity to feel suffering. ${ }^{28}$ Of key importance in this respect is the reservation that the provisions in respect of things may be applied to animals "accordingly". As established in the rulings of the Polish Supreme Court, the application of provisions of law "accordingly" means the need to apply the relevant provisions without any changes in a different scope of application, to apply them with some changes, or not to apply them..$^{29}$ In the context of the implementation of Article 1 (2) APA, this may mean the need to apply the provisions on things directly to animals without any modifications, to apply them with amendments resulting from the characteristics of an animal as a living being, or to exclude the application of these provisions on the grounds of irrelevance or contradiction with the provisions regulating the status of animals. In this respect, dereification is equivalent to the introduction of a general clause which makes distinctions on account of the specific subject-matter of the legal relationship between the legal régime for animals and that for things. ${ }^{30}$ The essence of this solution is that the legislator does not prejudge which of these régimes should apply in a given situation. The onus of deciding which régime is appropriate lies with the authority applying the law in concreto, and it is this authority which decides on applying to animals the legal régime relating to things "accordingly". ${ }^{31}$ According to this view, the formula for the dereification of an animal includes the requirement addressed to the authority which applies a given provision to an animal to consider whether or not this provision requires an appropriate reinterpretation, in view of the fact that the subject is an animal, i.e.

${ }^{27}$ Cf. E. Gniewek, [in:] Kodeks cywilny..., eds. E. Gniewek, P. Machnikowski, commentary on Article 45, side note 4.

${ }^{28}$ Cf. E. Łętowska, op. cit., pp. 85-86.

${ }^{29}$ Cf., i.a., resolution of the Supreme Court of 6 December 2000, III CZP 41/00, Legalis; resolution of the Supreme Court of 23 August 2006, III CZP 56/06, OSNC 2007, no. 3, item 43; judgement of the Supreme Court of 15 February 2008, I CSK 357/07, Legalis.

${ }^{30}$ E. Łętowska, op. cit., p. 83.

31 Ibidem. 
a living being capable of suffering. ${ }^{32}$ The decision on how to apply the provision concerning things to an animal in an appropriate manner should be made taking into account both the letter of the law and the axiology underlying the regulation aimed at protecting animals. ${ }^{33}$ In this respect, court rulings emphasise that it follows from Article 1 (1) APA that every animal has the right to expect from humans due understanding, treatment in accordance with the accepted norms, and even respect, and any legal measures taken in relation to animals should take into account their welfare, and above all their right to exist. ${ }^{34}$

\section{AN ANIMAL AS THE OBJECT OF LEGAL RELATIONSHIPS - THE CONCEPT OF THE RIGHT TO OWN AN ANIMAL}

The normative dereification of animals does not imply their exclusion, as living beings, from the categories of entities which can constitute the object of a legal relationship, in particular a civil-law relationship. ${ }^{35}$ The obligation arising from Article 1 (2) APA to apply to animals the provisions concerning things accordingly stipulates that animals, just like things, may be the object of rights and relationships of a civil-law nature. Living animals may be the object of property rights (in rem), trade, and legal transactions, subject to the proper application of provisions concerning things as the recipients of rights. ${ }^{36}$ Due to the lack of a detailed regulation in Polish law concerning the principles of the possession and disposal of animals, it is necessary in this respect to apply the provisions on property rights, in particular on ownership. In the approach adopted by the rulings of Polish courts and the Polish legal literature, the correct application of the provisions regulating "rights to things" is not, however, reduced to the simple adoption of these provisions as the basis for the assessment of legal statuses, the object of which is an animal, but leads to the distinction of specific forms of possessing an animal based on the "right to an animal", including in particular the "ownership of an animal". According to the view expressed by the Supreme Administrative Court, the effect of the normative dereification of animals is that the equivalent of the property right to a thing is the property right to an animal. ${ }^{37}$

32 Ibidem. Cf. judgement of the Supreme Administrative Court of 3 November 2011, II OSK $1628 / 11$, CBOSA.

${ }^{33}$ Cf. E. Łętowska, op. cit., p. 83.

${ }^{34}$ Judgement of Voivodeship Administrative Court in Gdańsk of 6 June 2013, IV SA/Po 165/13, CBOSA.

${ }_{35}$ M. Nazar, op. cit., p. 134.

36 S. Rudnicki, [in:] S. Dmowski, S. Rudnicki, Komentarz do Kodeksu cywilnego. Księga pierwsza. Część ogólna, Warszawa 1999, p. 139.

37 Judgement of the Supreme Administrative Court of 3 November 2011, II OSK 1628/11, CBOSA. 
This right is characterised as an absolute right, with the attributes of a property right, but differing from property, because of the rules on the protection of animals, in the object and manner of exercising analogous attributes. ${ }^{38}$ This right gives far fewer possibilities for the using and disposing of an animal than the right of the ownership of an object. The ownership of an animal primarily obliges, and the scope and content of the rights towards the animal are modified by, the necessity of its humane treatment. ${ }^{39}$ Contrary to the right of the ownership of a thing, the right of the ownership of an animal does not provide, e.g., the possibility to abandon the animal, as such behaviour is treated in the light of Article 6 (2) (11) APA as a manifestation of the abuse of an animal. While the right of ownership of a thing includes the possibility to destroy it, the killing of an animal is allowed only in legally specified situations. Due to the differences between the ownership of an animal and the property right, in the Polish literature it is referred to as property in the figurative sense, which is the right to objects of a different kind from a thing ${ }^{40}$ or as quasi-property. ${ }^{41}$ The same remarks can also be made with regard to possession, understood as the actual control of an animal, as well as contractual transactions, the objective of which is the sale, lease, rental, or lending of an animal.

\section{THE DEREIFICATION OF ANIMALS AND THEIR LEGAL PROTECTION}

The normative dereification of animals enacted on the basis of Article 1 (1) APA results in animals' being subject to special protection, which is aimed, on the one hand, at protecting the animal as a living being, and, on the other, as an object of trade and the interests of the person who has the ownership right to the animal.

According to the rulings of the Supreme Court, the consequence of dereification is the creation of a system of legal protection for animals, which requires humans to treat them in a certain way, taking into account the orders and prohibitions ${ }^{42}$ prescribed in the Animal Protection Act. People should, in relation to animals, act in a manner appropriate to living beings capable of certain feelings (e.g., suffering) and not to objects (things). ${ }^{43}$ Article 1 (1) APA, by stipulating that an animal is not a thing, defines it as a living being capable of experiencing suffering. At the same time, this provision states that people owe respect, protection, and care to animals. Consequently, animals are given special safeguards. The law prohibits the abuse

\footnotetext{
${ }^{38}$ M. Nazar, op. cit., p. 134.

39 Judgement of the Supreme Administrative Court of 12 March 2019, II OSK 1066/17, CBOSA.

${ }^{40}$ M. Nazar, op. cit., p. 134.

41 W. Daniłowicz, Prawo towieckie, Warszawa 2020, p. 109.

${ }^{42}$ Resolution of the Supreme Court of 20 June 2012, I KZP 4/12, Legalis.

43 Judgement of the Supreme Administrative Court of 12 March 2019, II OSK 1066/17, CBOSA.
} 
of animals. The killing of an animal is only permissible in the situations listed in the Animal Protection Act, and must be carried out in a humane manner, causing a minimum of physical and mental suffering to be inflicted. Pursuant to Article 35 APA, the abuse of an animal, as well as the killing of an animal in situations which are not provided for by law, or without complying with the requirements concerning the manner in which the animal is killed, is an offence punishable by imprisonment of up to 3 years, and if the perpetrator acts with particular cruelty, by imprisonment of between 3 months and up to 5 years.

The fact that an animal may be the object of a legal relationship means that under Polish law it is also protected as an object of a subject's right to an animal. Under Polish civil law, the killing, injuring, or causing disease in an animal gives rise to the necessity to compensate for the damage under the same rules as in the event of destruction or damage to another person's thing. ${ }^{44}$ Correspondingly, the body of knowledge on Polish criminal law assumes that the killing of an animal belonging to another person constitutes the destruction of another person's thing. ${ }^{45}$ This offence is regulated by Article $288 \S 1$ of the Act of 6 June 1997 - Penal Code ${ }^{46}$ under which anyone who destroys, damages, or renders useless another person's thing is subject to imprisonment for a term of between 3 months and 5 years. In such cases, the basis for the responsibility of a perpetrator who has killed an animal are cumulatively set out in Article 35 (1), which penalises the killing of an animal in violation of the conditions prescribed in the Act, and in Article $288 \S 1$ of the Penal Code, which similarly punishes the destruction of another person's thing. ${ }^{47}$

\section{AN ASSESSMENT OF THE CONCEPT OF THE NORMATIVE DEREIFICATION OF ANIMALS IN THE POLISH LEGAL LITERATURE}

The Polish legal literature presents diverse views on the status of animals. In the period preceding the adoption of the Animal Protection Act, which precipitated this dereification, there were both voices criticising the reistic concept of the treat-

${ }^{44}$ Likewise, i.a., P. Księżak, [in:] Kodeks cywilny. Część ogólna. Komentarz, ed. M. Pyziak-Szafnicka, Warszawa 2009, p. 279; A. Szpunar, Odszkodowanie za szkode majątkowa. Szkoda na mieniu i osobie, Bydgoszcz 1998, p. 63; M. Nesterowicz, Zadośćuczynienie pieniężne i odszkodowanie za śmierć lub uszkodzenie psa „,rodzinnego" na skutek czynu niedozwolonego (w świetle orzecznictwa), "Przegląd Sądowy" 2019, no. 5, pp. 115-130.

${ }^{45}$ Por. W. Radecki, [in:] M. Bojarski, W. Radecki, Pozakodeksowe prawo karne, Warszawa 2002, p. 373; M. Kulik, M. Mozgawa, Zbieg przepisu art. 35 ustawy o ochronie zwierząt z przepisami typizującymi uszkodzenie rzeczy, "Prokuratura i Prawo" 2011, no. 6, pp. 5-22; M. Gabriel-Węglowski, Przestępstwa przeciwko humanitarnej ochronie zwierząt, Toruń 2008, p. 142.

${ }^{46}$ Consolidated text, Journal of Laws 2020, item 1444, as amended.

${ }^{47}$ Cf. W. Radecki, [in:] M. Bojarski, W. Radecki, op. cit., p. 142. 
ment of animals ${ }^{48}$ and those strongly opposing the notion of the dereification of animals. ${ }^{49}$ Also the assessment of the effects of the entry into force of Article 1 (1) APA is not uniform. On the one hand, it is pointed out that the dereification enacted on the basis of this provision positions animals in the dignified legal and moral dimension corresponding to their nature. ${ }^{50}$ The importance of dereification is also emphasised in the axiological dimension; it is pointed out that it makes the subjects of legal norms aware that the provisions on objects may be applied to animals only as a matter of a legal device, and only insofar as this is not excluded or modified by special provisions relating to animals and the human-animal relationship. ${ }^{51} \mathrm{On}$ the other hand, it is pointed out that, from the normative as well as the utilitarian points of view, the dereification of animals was not necessary in order to protect them from human behaviour likely to cause them pain and suffering, since, even if it had not been enacted, the holder of the right to an animal, in exercising the attributes of his or her right, would have had to comply with the provisions protecting animals, and it would have been those provisions which would have set the limits and the manner of exercising that right..$^{52}$ At the same time, it is noted here that the reistic concept of the status of animals is not dictated by a negative attitude towards animals, but is rather the legacy of a long-established civil-law tradition and the restriction of the legal regulation of animals to only those matters which are dictated by the special nature of animals as objects of legal transactions, and the consequences connected with such transactions. ${ }^{53}$ According to this position, maintaining the reistic status of animals does not necessarily imply the approval of the morally reprehensible treatment of animals if the legal system had appropriately constructed and properly enforced the animal-protection laws, ${ }^{54}$ and it is a gross oversimplification to attribute to the proponents of anthropocentrism cruelty towards or an aversion to, animals, and the glorifying of animal abuse. ${ }^{55}$

In this context, it is worth noting that the Polish literature quite consistently rejects the concept of the personification of animals, understood as granting animals legal subjectivity. The literature notes that the protection of animals does not require equipping them with subjective rights, as the welfare of animals may be sufficiently secured by the so-called legal reflections, which is the legal reflection

${ }^{48}$ I. Lazari-Pawłowska, Zwierzę nie jest rzecza, [in:] Etyka. Wybrane pisma, ed. P. Smoczyński, Wrocław 1992, pp. 481-491.

49 T. Majewicz, Zwierze - przedmiot czy podmiot prawa, “Życie Weterynaryjne” 1996, no. 4, pp. 97-98.

${ }^{50}$ M. Nazar, op. cit., p. 150.

${ }^{51}$ Ibidem, pp. 149-150.

${ }_{52}$ Ibidem, p. 149.

${ }^{53}$ E. Łętowska, op. cit., p. 81.

${ }^{54}$ M. Nazar, op. cit., p. 149.

${ }^{55}$ E. Łętowska, op. cit., p. 75. 
of the obligations imposed by animal-protection legislation, ${ }^{56}$ and that many standards of protection of animals is also fully achievable on the basis of the conceptual apparatus currently accepted in positive law - in which animals are not assigned rights, while other legal entities are subject to obligations which protect animal welfare. ${ }^{57}$ It is also stressed that the possession of legal personality does not render the rights granted to a given subject inviolable. ${ }^{58}$ Consequently, simply granting legal capacity and subjective rights to animals would be insufficient. At the same time, it is emphasised that granting legal capacity to animals would disrupt the stable and rational order of the legal system. ${ }^{59}$

\section{CONCLUSIONS}

When assessing the importance of the interpretative directive contained in Article 1 (1) APA, which is based on the statement that an animal is not a thing, the Polish Supreme Court expressed the view that in recent years in Poland there had been a radical re-evaluation of human relationships with animals, which meant that they had become contrasted with things, and the notion that they had become part of the world of living beings capable of suffering had been recognised, and humans had become obliged to respect animals, protect them, and guarantee their care ${ }^{60}$ Undoubtedly, one should agree that the direct statement in the provision of Article 1 (1) APA that an animal is not a thing constitutes a breakthrough in the perception of animals in the normative dimension. The aforementioned directive became the basis of the animal-protection model adopted in the Polish legal system and significantly contributed to strengthening the legal protection of an animal as a living being capable of experiencing suffering. It is not without significance that it is, in a way, a compromise solution, reconciling, at least partially, the assumptions of the concepts of the reification and personification of animals. On the one hand, it makes it possible to preserve the traditional system, in which only human beings, legal persons, and organisational units provided with legal capacity by the legislator have legal subjectivity, and the legal instruments (in particular civil-law instruments) based on this system. On the other hand, it makes it possible to break with the normative treatment of an animal as a thing. The introduction in Article 2 (1) APA of the possibility to apply the provisions on things to animals accordingly

${ }^{56}$ M. Nazar, op. cit., pp. 138-139.

57 T. Pietrzykowski, Prawo ochrony zwierząt - między praktyka a teoria nowej gatęzi prawa. Artykut recenzyjny dotyczacy ksiązki Prawa zwierząt. Praktyczny przewodnik, "Krytyka Prawa" 2020, vol. 12(2), p. 213.

${ }^{58}$ E. Łętowska, op. cit., p. 88.

${ }^{59}$ M. Nazar, op. cit., p. 139.

${ }^{60}$ Judgement of the Supreme Court of 13 December 2016, II KK 281/16, Legalis. 
freed the legislator from the necessity to regulate separately the status of animals as the object of legal relationships, which in many aspects is, in fact, almost the same as the status of things, thus contributing to the cohesion of the legal system, and, on the other hand, protects animals from an entirely objective treatment resulting from the necessity to directly apply, in order to determine their legal situation, provisions which were originally drafted with the intention to determine the principles of the possession and disposal of objects, without taking into account the different nature of animals as living beings. In this respect, the adopted solutions should be assessed as fully positive.

What might raise some doubts, however, is the fact that the regulation determining the manner in which an animal is perceived in the normative dimension was included in the provisions of an ordinary Act. It seems that it would be more appropriate to include it in regulations on constitutional statuses, or at least (as in, e.g., Austria and Germany), as in the provisions of the Civil Code. Such a solution would, on the one hand, eliminate the doubts currently arising as to the scope of the normative dereification of animals, and, on the other, could contribute to enhancing public awareness of the legal status of animals.

\section{REFERENCES}

\section{Literature}

Białocerkiewicz J., Status prawny zwierząt. Prawa zwierząt czy prawna ochrona zwierząt, Toruń 2005. Daniłowicz W., Prawo towieckie, Warszawa 2020.

Gabriel-Węglowski M., Przestępstwa przeciwko humanitarnej ochronie zwierząt, Toruń 2008. Gniewek E., [in:] Kodeks cywilny. Komentarz, eds. E. Gniewek, P. Machnikowski, Legalis 2019. Goettel M., Sytuacja zwierzęcia w prawie cywilnym, Warszawa 2013.

Goździewicz-Biechońska J., Jachnik E., Legal Status of the Animal as a Determinant of Its Humanitarian Protection, "Studia Iuridica Lublinensia" 2021, vol. 30(3),

DOI: http://dx.doi.org/10.17951/sil.2021.30.3.67-79.

Helios J., Jedlecka W., Ławniczak A., Aspekty prawne, filozoficzne oraz religijne ochrony roślin $i$ zwierzat - wybrane zagadnienia, Wrocław 2016.

Kruk E., Legal Status of Animals in Poland, "Studia Iuridica Lublinensia" 2021, vol. 30(3),

DOI: http://dx.doi.org/10.17951/sil.2021.30.3.119-131.

Księżak P., [in:] Kodeks cywilny. Część ogólna. Komentarz, ed. M. Pyziak-Szafnicka, Warszawa 2009.

Księżak P., [in:] Kodeks cywilny. Komentarz, ed. K. Osajda, Legalis 2021.

Kulik M., Mozgawa M., Zbieg przepisu art. 35 ustawy o ochronie zwierzą z przepisami typizujacymi uszkodzenie rzeczy, "Prokuratura i Prawo" 2011, no. 6.

Lazari-Pawłowska I., Zwierzę nie jest rzecza, [in:] Etyka. Wybrane pisma, ed. P. Smoczyński, Wrocław 1992.

Łętowska E., Dwa cywilnoprawne aspekty praw zwierząt: dereifikacja i personifikacja, [in:] Studia z prawa prywatnego. Księga pamiątkowa ku czci Profesor Biruty Lewaszkiewicz-Petrykowskiej, Łódź 1997. 
Majewicz T., Zwierze - przedmiot czy podmiot prawa, “Życie Weterynaryjne” 1996, no. 4.

Nazar M., Normatywna dereifikacja zwierzat - aspekty cywilnoprawne, [in:] Prawna ochrona zwierzat, ed. M. Mozgawa, Lublin 2002.

Nesterowicz M., Zadośćuczynienie pieniężne i odszkodowanie za śmierć lub uszkodzenie psa , rodzinnego" na skutek czynu niedozwolonego (w świetle orzecznictwa), "Przegląd Sądowy" 2019, no. 5.

Pietrzykowski T., Prawo ochrony zwierząt - między praktyka a teoria nowej gatęzi prawa. Artykut recenzyjny dotyczacy książki Prawa zwierząt. Praktyczny przewodnik, "Krytyka Prawa" 2020, vol. 12(2).

Radecki W., [in:] M. Bojarski, W. Radecki, Pozakodeksowe prawo karne, Warszawa 2002.

Radecki W., Ustawa o ochronie zwierzat, Wrocław 2003.

Radwański Z., Prawo cywilne. Część ogólna, Warszawa 1999.

Rakoczy B., Protection of Animals and Protection from Animals, "Studia Iuridica Lublinensia" 2021, vol. 30(3), DOI: http://dx.doi.org/10.17951/sil.2021.30.3.161-172.

Rudnicki S., [in:] S. Dmowski, S. Rudnicki, Komentarz do Kodeksu cywilnego. Księga pierwsza. Część ogólna, Warszawa 1999.

Strugała R., [in:] Kodeks cywilny. Komentarz, eds. E. Gniewek, P. Machnikowski, Legalis 2019.

Szpunar A., Odszkodowanie za szkodę majątkowa. Szkoda na mieniu i osobie, Bydgoszcz 1998.

Żelechowski Ł., [in:] Kodeks cywilny. Komentarz, ed. K. Osajda, Warszawa 2021.

\section{Legal acts}

Act of 23 April 1964 - Civil Code (consolidated text, Journal of Laws 2020, item 1740, as amended). Act of 6 June 1997 - Penal Code (consolidated text, Journal of Laws 2020, item 1444, as amended). Act of 21 August 1997 on animal protection (consolidated text, Journal of Laws 2020, item 638).

Constitution of the Republic of Poland of 2 April 1997 (Journal of Laws 1997, no. 78, item 483, as amended).

Regulation of the President of the Republic of Poland of 22 March 1928 on the protection of animals (Journal of Laws 1932, item 417, as amended).

\section{Case law}

Judgement of the Supreme Administrative Court of 3 November 2011, II OSK 1628/11, CBOSA. Judgement of the Supreme Administrative Court of 12 March 2019, II OSK 1066/17, CBOSA. Judgement of the Supreme Court of 15 February 2008, I CSK 357/07, Legalis. Judgement of the Supreme Court of 13 December 2016, II KK 281/16, Legalis. Judgement of Voivodeship Administrative Court in Gdańsk of 6 June 2013, IV SA/Po 165/13, CBOSA. Judgement of the Voivodeship Administrative Court in Kraków of 13 September 2016, II SA/Kr 398/16, CBOSA.

Resolution of the Supreme Court of 6 December 2000, III CZP 41/00, Legalis.

Resolution of the Supreme Court of 23 August 2006, III CZP 56/06, OSNC 2007, no. 3, item 43. Resolution of the Supreme Court of 20 June 2012, I KZP 4/12, Legalis. 


\begin{abstract}
ABSTRAKT
Przedmiotem opracowania jest normatywna dereifikacja zwierzęcia, która została dokonana w systemie polskiego prawa na podstawie przepisów ustawy z dnia 21 sierpnia 1997 r. o ochronie zwierząt. Przepisy te wskazują, że zwierzę jako istota żyjąca, zdolna do odczuwania cierpienia, nie jest rzeczą, i jednocześnie zastrzegają potrzebę odpowiedniego stosowania do zwierząt, w sprawach nieuregulowanych w tej ustawie, przepisów o rzeczach. Celem opracowania jest określenie znaczenia tak dokonanej dereifikacji dla określenia statusu prawnego zwierzęcia w polskim prawie oraz wpływu, jaki wywiera ona na kształt modelu ochrony zwierząt w Polsce. Podstawą ustaleń w tym zakresie jest formalno-dogmatyczna analiza aktów polskiego prawa regulujących zasady ochrony zwierząt oraz ich status jako przedmiotu stosunku prawnego. Opracowanie porządkuje i podsumowuje poglądy na temat prawnego statusu zwierzęcia oraz koncepcji jego normatywnej dereifikacji wyrażane w orzecznictwie polskich sądów i w polskiej literaturze prawniczej.
\end{abstract}

Słowa kluczowe: zwierzę; dereifikacja; reifikacja; ochrona zwierząt; status prawny zwierzęcia; polskie prawo 